ISSN: $1896-382 \mathrm{X}$ | www.wnus.edu.pl/epu

DOI: 10.18276/epu.2017.126/1-15 | strony: 141-148

\title{
Bogusław Kaczmarek
}

Uniwersytet Łódzki

Katedra Zarządzania

e-mail: b.kaczmarek@uni.lodz.pl

\section{Uwagi o współczesnym zarządzaniu na tle procesów internacjonalizacji przedsiębiorstw}

Kod JEL: A10

Słowa kluczowe: zarządzanie, globalizacja, internacjonalizacja, przedsiębiorstwo

Streszczenie. W opracowaniu akcentowane jest stwierdzenie, że internacjonalizacja generuje zupełnie nowy system wyznaczników pracy, działalności przedsiębiorstw i ich menedżerów na międzynarodowych rynkach. Analizowane są - zdaniem autora - najważniejsze wyznaczniki (problemy), które powstają wtedy, kiedy przedsiębiorstwo umiędzynaradawia swoją działalność.

\section{Wprowadzenie}

Globalizacja - jak pisze G. Kołodko - to ,proces, dzięki któremu nie tylko pojawiają się nowe szanse i wyzwania dla przedsiębiorstw, wynikające $\mathrm{z}$ faktu, że te przedsiębiorstwa (firmy) stają się coraz bardziej otwarte na różnego rodzaju związki z zagranicą" (Kołodko, 2013, s. 97). Proces globalizacji wiązany jest najczęściej z przenikaniem się rynków, zacieraniem granic i łamaniem wszelkich barier.

Rozwijający się dzięki globalizacji proces internacjonalizacji (umiędzynarodowienia) przedsiębiorstwa to charakterystyczna i stale rozwijająca się cecha współczesnej gospodarki. Poza możliwościami stwarzanymi przez globalizację, głównym powodem internacjonalizacji przedsiębiorstw jest zanikanie wielu krajowych nisz, rosnąca konkurencja w kraju macierzystym, nasycenie rynkowe i wzrost wymagań klientów ${ }^{1}$. Trudno wyobrazić sobie dzisiaj przedsiębiorstwa, które nie chciałyby funkcjonować na rynkach zagranicznych i umiędzynarodawiać swoją gospodarkę i sprzedaż.

${ }^{1}$ Internacjonalizacja najczęściej definiowana jest jako stopień zaangażowania przedsiębiorstwa w prowadzenie działalności na rynkach zagranicznych. 
Wybór drogi procesu internacjonalizacji przedsiębiorstwa zależy od bardzo wielu czynników (Vernon, 2006), między innymi od szeroko rozumianych zasobów firmy, jej otoczenia krajowego i międzynarodowego, skłonności top menedżerów do podejmowania złożonych i trudnych wyzwań, jakie stwarza umiędzynarodowienie działalności gospodarczej przedsiębiorstwa. W teorii i praktyce zarządzania przedstawiane i analizowane są różne modele (drogi) procesu internacjonalizacji przedsiębiorstw (Schoppe, 2006, s. 134$)^{2}$, traktowane jako różne sposoby wchodzenia i funkcjonowania na rynkach zagranicznych.

W niniejszym artykule główną uwagę skupiono na problemach i zadaniach pojawiających się w zarządzaniu współczesnym przedsiębiorstwem, które wchodzi w proces internacjonalizacji swojej działalności.

\section{Cechy charakterystyczne internacjonalizacji przedsiębiorstw}

Jedną z najbardziej charakterystycznych cech współczesnej gospodarki światowej - związanej z globalizacją i liberalizacją handlu międzynarodowego, jest internacjonalizacja przedsiębiorstw i rosnąca dynamika konkurencji w złożonym otoczeniu. Brakuje jednak modeli opisujących całościowe podejście do tych procesów, pozwalających na analizę relacji zachodzących w złożonych systemach gospodarczych, umożliwiających poznanie struktury systemu i jego dynamiki, szczególnie, gdy trzeba uwzględnić wiele zmiennych o charakterze egzogenicznym, ułatwiających uchwycenie złożoności sytuacji konkurencyjnej i dostosowania działań łączących się w organizacji. Działające w takim otoczeniu organizacje muszą się zmieniać, tworzyć nowy zestaw możliwości uwzględniając przy tym trzy grupy czynników: zasoby, procesy i wartości, a także to, że w miarę wzrostu i powiązań międzynarodowych coraz większą rolę odgrywają procesy i wartości oraz zasoby w postaci wiedzy. Musi je cechować restrukturyzacja jako wymóg racjonalności działania i wzrostu konkurencyjności oraz tworzenie powiązań z otoczeniem skierowanych na efektywną alokację zasobów, odpowiadającą oczekiwaniom przedsiębiorstwa (zasada kongruencji).

Przedsiębiorstwa więc muszą poszukiwać szans na trwanie i rozwój dzięki wszechstronnemu wglądowi w to, co najbardziej fundamentalne w „nowej gospodarce”, naturze organizacji i jej globalnego otoczenia i co ułatwia ich dostosowanie do zmieniających się warunków działania i rozwoju współpracy między przedsiębiorstwami.

W literaturze proces ten określa się często mianem dynamicznej stabilności (dynamic stability), polegającej na tym, że udoskonalenie należy zaczynać od poszukiwania pomysłów wewnątrz organizacji, uwzględniając naturalnie nowe wyzwania i nowe możliwości, jakie daje gospodarka regionalna (glokalizacja). Stawiać jednak należy na innowacje i stosowanie nowoczesnej wiedzy, bo zdolność organizacji do uczenia się i szyb-

2 Najbardziej znany to model amerykański, szwedzki, fiński oraz modele stworzone poprzez sieć współpracy oparte na innowacjach. 
kiego „przekuwania” wiedzy w działanie przyczynia się do uzyskania dzisiaj największej przewagi konkurencyjnej. Współczesne organizacje stawiają zatem na pierwszym miejscu klienta i pozyskują go przewagą oferowanych mu wartości, produktów, towarów lub usług (economic value to the customer).

Organizacja musi też uwzględniać paradygmat społecznej gospodarki rynkowej, której główną ideą jest dążenie do połączenia w jedną spójną całość wymogów konkurencyjności, społecznej solidarności i wolności demokratycznych. W nowych założeniach strategii gospodarki odchodzi się od agresywnego przedsiębiorczego kapitalizmu, w którym główną ideą jest wiara w samoregulujący się rynek, co prowadzi do strategicznej krótkowzroczności (strategie myopia), wielkich nierówności społecznych i kumulacji bogactwa w rękach elit biznesu.

Istnieje więc konieczność nieschematycznej analizy uwarunkowań i sukcesów organizacji przechodzących procesy internacjonalizacji, poszukiwania odpowiedzi na efektywne funkcjonowanie firmy w międzynarodowym biznesie, gdzie wiedza i innowacje stają się decydujące dla kreowania sukcesu.

Obserwacja rzeczywistości, szczególnie jej gospodarczego wymiaru, dostarcza wiele refleksji i koncepcji kreowania organizacji przedsiębiorstwa na arenie międzynarodowej. Z obserwacji tej wynika jednoznacznie, że każde przedsiębiorstwo, które chce zająć dobrą pozycję na rynku i wśród konkurencji musi mieć indywidualną i wyróżniającą się tożsamość (corporate identity), na którą składa się zachowanie, wizja i reputacja przedsiębiorstwa w społeczności lokalnej. Musi też mieć własny model działania, który uwzględnia jakie czynniki i w jaki sposób wpływają na tożsamość organizacji, wyróżniające ją kompetencje (distinctive competences) i formułowane oraz realizowane strategie działania.

Szczególnie ciekawe i pomocne w tworzeniu takiego modelu mogą być badania prowadzone przez różnych autorów, które wykazują, jak poszczególne przedsiębiorstwa radzą sobie $z$ wchodzeniem i prowadzeniem działalności na rynkach międzynarodowych. Tego typu studia przypadków ułatwiają menedżerom zrozumienie konieczności i metod dostosowywania się do konkurencji, panującej na tych rynkach. Szczególnie ważne w tym względzie jest programowanie rozwoju przedsiębiorstwa w sposób zgodny ze społeczną racjonalnością działań gospodarczych i postępowań według triady: korzyści globalizacji - najlepsze praktyki - skuteczne zarządzanie.

\section{Problemy internacjonalizacji przedsiębiorstwa}

We współczesnej gospodarce firma musi dbać nie tylko o zapewnienie sobie odpowiedniej zdolności konkurencyjnej, oczywiście przestrzegając przy tym zasad etycznych, ale też spełniać oczekiwania różnych interesariuszy (stakeholders), gdyż:

- właściciele pragną doskonałej jakości działalności gospodarczej i zarządzania,

- klienci chcą towarów wartych ceny i wysokiej jakości usług, 
- pracownicy chcą wysokiej jakości warunków pracy i godziwego wynagrodzenia,

- społeczeństwo pragnie akceptowanej jakości społecznej odpowiedzialności przedsiębiorstwa.

Internacjonalizacja zatem - jako nieodwracalny już proces - generuje zupełnie nowy system wyznaczników pracy i działalności (zachowań) przedsiębiorstwa i jego menedżerów na międzynarodowych rynkach. Te wyznaczniki - problemy sprowadzić można do następującej enumeracji.

1. Globalizacja działalności gospodarczej jako postępujący proces integrowania coraz większej liczby krajowych gospodarek i przedsiębiorstw odbywa się ponad granicami państwowymi, co stawia przedsiębiorstwa w zupełnie nowej sytuacji technicznoprodukcyjnej, organizacyjno-zarządczej czy ekonomiczno-społecznej.

2. Internacjonalizacja to zaawansowany i złożony proces umiędzynarodowienia działalności przedsiębiorstwa, polegającej m.in. na scalaniu, powiązaniu i koordynowaniu działań lub zadań w różnych jednostkach organizacyjnych w kraju i za granicą.

3. Rozszerzanie się procesu internacjonalizacji, jego logika, wielość powiązań i wzajemności oddziaływań przedsiębiorstw tworzy „nowy wielowymiarowy system ekonomiczny", zawierający m.in. takie czynniki jak: politykę państwa, regulacje prawne, bariery wejścia, dostępność zasobów, rynek pracy, rynek finansowy. Wszystkie te wymienione i inne czynniki muszą być ze sobą skoordynowane.

4. Dążenie do uzyskania przewagi konkurencyjnej przedsiębiorstwa, tj. osiągania wyższej rentowności niż inne przedsiębiorstwo działające w danej branży polega na poszerzeniu łańcucha wartości dodanej, co usprawnia funkcjonowanie przedsiębiorstwa na danym rynku.

5. Dążenie do uzyskania kluczowych kompetencji (core competencies), decyduje o powodzeniu rywalizacji o przyszłe przywództwo na rynku, a także o przyszłości przedsiębiorstwa. To jest kluczowe zadanie dla przedsiębiorstwa funkcjonującego na rynkach zagranicznych.

6. Zacieśnia się związek postępu nauki i techniki oraz postęp organizacyjny z zakresem międzynarodowej działalności przedsiębiorstwa. Wiedza i innowacje stają się decydujące dla konkurencyjności przedsiębiorstwa. Majątek intelektualny staje się ważniejszy niż materialny. W wielu firmach sposób wykorzystania kapitału ludzkiego i jego doskonalenie decyduje o wartości i sukcesie firmy. Ułatwia to też poszukiwanie i stosowanie innowacyjnych modeli biznesu.

7. Rośnie rola sojuszy między przedsiębiorstwami, dążenie do integracji dla prowadzenia wspólnych przedsięwzięć i współpracy pomiędzy przedsiębiorstwami. Globalizacja i internacjonalizacja generują nowy system wyznaczników sukcesu i awansu przedsiębiorstwa, nowy jego model zwany sustainable enterprise. Jest to koncepcja przedsiębiorstwa przyszłości, które zdolne będzie przetrwać nawet najgłębsze kryzysy i rozwijać się, szukając szans w niestabilnym otoczeniu. Takie 
przedsiębiorstwo ma zdolność i gotowość do wprowadzania programowalnych zmian, czyli zdolność do odnawiania się na wyższym poziomie.

8. Rośnie znaczenie logistyki w sterowaniu przepływem towarów i informacji, eliminowaniu czasu i kosztów, które nie przyczyniają się do tworzenia nowej wartości. Logistyka staje się ważnym czynnikiem kreowania konkurencyjności i budowy strategii przedsiębiorstwa. W Unii Europejskiej np. rozwijana jest eurologistyka, co ułatwia usprawnianie łańcucha dostaw na terenie Europy. Przedsiębiorstwa tworzą łańcuchy logistyczne, które łączą sferę procesu produkcyjnego ze sferami zaopatrzenia i dystrybucji. Łączą też przedsiębiorstwa kooperujące i współdziałające ze sobą.

9. Utrwalania się nowej międzynarodowej kultury przedsiębiorczości, w której rośnie znaczenie ogólnych prakseologicznych zasad zarządzania, a jednocześnie tożsamości narodu i stylu zarządzania zdeterminowanego kulturą danego kraju. Powstaje nowy styl zarządzania - zarządzanie międzykulturowe, które uwzględnia potrzeby i motywacje ludzi pochodzących z więcej niż jednej kultury. Wielokulturowość coraz mocniej wpływa na obszary działalności firm, stosunki międzyludzkie i negocjacje w międzynarodowym otoczeniu. Kultury otwarte, o niskim dystansie władzy, wysokiej skłonności do ryzyka, uniwersalistyczne, zorientowane na przyszłość zwiększają potencjalnie przewagę konkurencyjną przedsiębiorstw w dobie globalizacji i internacjonalizacji.

Postępujące umiędzynarodowienie biznesu sprawia, że przedsiębiorstwa muszą prowadzić swoją działalność na skrzyżowaniu różnych kultur z wykorzystaniem praktyk zarządzania międzynarodowego. Oznacza ono takie zarządzanie, w którym proces aplikacji koncepcji, metod i technik zarządzania odbywa się w wielokulturowym otoczeniu, a więc w otoczeniu o wiele bardziej złożonym niż otoczenie krajowe. Zarządzanie w przedsiębiorstwach międzynarodowych opisywane i przedstawiane jest w literaturze na dwa sposoby (Rozkwitalska, 2007, s. 23). Pierwszy sposób polega na ukazaniu, jak i w jaki sposób zmieniają się treściowo, i w jakim kierunku zmieniają się funkcje zarządzania (czynności zarządzania), czyli planowanie strategiczne, organizowanie i motywowanie (przewodzenie) i kontrolowanie. Drugi sposób polega na precyzyjnym określeniu (wraz z odpowiednimi uwarunkowaniami prowadzenia działalności gospodarczej poza macierzystym krajem) wymiarów tego zarządzania takich jak:

- wymiar kulturowy,

- wymiar zarządzania zasobami ludzkimi,

- wymiar zarządzania finansami i teorie funkcjonowania nadzoru właścicielskiego,

- wymiar marketingu i strategii międzynarodowej,

- wymiar społecznej odpowiedzialności przedsiębiorstw międzynarodowych (Kreitner, Kinicki, 2011, s. 506). 
10. Rośnie znaczenie społecznej odpowiedzialności przedsiębiorstw (corporate social responsibility). Współcześnie społeczna odpowiedzialność przedsiębiorstw staje się znakiem „nowego gospodarczego porządku” (Bloom, Calori, de Woot, 1995, s. 66) polegającego na tym, że przedsiębiorstwo pozytywnie odpowiada na oczekiwania zróżnicowanego otoczenia (czyli instytucji i osób które go tworzą) i ma pewne zobowiązania społeczne; pewien rodzaj obywatelskiej roli do spełnienia zarówno w obszarze społecznym (prawa pracownika, dbanie o rozwój zawodowy pracowników), ekonomicznym (terminowa regulacja zobowiązań, jawność i rzetelność informacji o działalności firmy) i ekologicznym (dbałość o ochronę środowiska naturalnego). Społeczna odpowiedzialność firm nabiera szczególnego znaczenia w przedsiębiorstwach międzynarodowych ze względu na specyfikę ich działalności. Na przedsiębiorstwo międzynarodowe (jego filie, przedstawicielstwa, dywizje) rozpoczynające działalność gospodarczą w danym kraju goszczącego „zwrócone są wszystkie oczy” społeczności lokalnej, a także władz administracyjnych jako na coś nowego, nieznanego, a jednocześnie dającego szansę na lepsze życie (por. Adamus-Matuszewska, 2016, s. 9). Z badań wynika, że przedsiębiorstwo międzynarodowe to szczególnego rodzaju ,inwestycja społeczna” (Maciąg, 2006, s. 32) powodująca wzrost aktywności społecznej ludzi, stwarzająca nowe możliwości pracy na danym terenie, umożliwiająca robienie kariery zawodowej, zwiększająca możliwości zagospodarowania danego terenu oraz powodująca wzrost rangi i znaczenia tego kraju w skali globalnej. Ludzie wierzą, że przedsiębiorstwo międzynarodowe - jako nowa firma - coś dla nich zrobi, da im szansę nowego, lepszego życia; nowego rozwoju, łączności ze światem, a tego typu nadziei nie sposób nie spełnić. Społeczna odpowiedzialność przedsiębiorstw oznacza dobrowolne łączenie spraw społecznych i gospodarczych w działalności handlowej i stosunkach z interesariuszami (stakeholders). Przedsiębiorstwo zwraca większa uwagę na swe koszty społeczne i staje się bardziej świadome tego, co jego działalność wywołuje na rynku i w otoczeniu, w którym działa. Społeczna odpowiedzialność biznesu znajduje swoje podłoże na gruncie etyki biznesu. Odchodzi się dzisiaj coraz bardziej od patrzenia na działalność przedsiębiorców wyłącznie pod kątem wysokości kreowanego przez nich zysku. Zysk ten powinien być postrzegany w kontekście przestrzegania zasad etycznych przez przedsiębiorcę, który powinien wykazać troskę o to, by postępować moralnie i nienagannie, by jego działanie wnosiło wkład w polepszenie funkcjonowania społeczeństwa i ochronę środowiska naturalnego.

Internacjonalizacja wiąże się też z szansami na bardziej korzystną pozycję w międzynarodowym podziale pracy, ułatwia integrację z gospodarką światową i eksport produktów, towarów i usług. Internacjonalizacja otworzyła przed przedsiębiorstwami nowe perspektywy, ale też przyczyniła się do zwiększenia złożoności ich organizacji i stylów zarządzania. Pod jej wpływem powstaje nowy model rozwoju gospodarki, w którym obydwa wymiary: gospodarczy i społeczny muszą się łączyć, wzajemnie 
inspirować i kierować swoje działanie ku dobru wspólnemu. Dotyczy to szczególnie całej Europy, która realizuje postanowienia Strategii lizbońskiej (z 2000 r.). Ze strategią wiąże się nowy paradygmat rozwoju tej gospodarki i przekształcenia jej w obszar gospodarki dynamicznej - opartej na wiedzy. Jest to problem niezwykle ważny również dla Polski, gdyż przestrzeganie zasad Strategii lizbońskiej oznacza szansę na zmniejszenie dystansu rozwojowego naszej gospodarki, jaki dzieli nas od rozwiniętych krajów Europy i świata. Jeżeli mamy budować gospodarkę opartą na wiedzy, potrzebne jest silne wsparcie nauki. Potrzebne są propozycje i koncepcje, które wyzwoliłyby nowe impulsy i szanse kształtowania społeczeństwa wiedzy. Nauka powinna aktywnie uczestniczyć i wspierać proces budowania gospodarki, tworzyć gospodarkę rynkową, a nie społeczeństwo rynkowe; rozwijać ją w sposób zrównoważony z większymi możliwościami zatrudnienia i silniejszą rolą i znaczeniem społecznej gospodarki rynkowej.

\section{Podsumowanie}

Generalnie można i trzeba zauważyć, że procesy internacjonalizacji przedsiębiorstw powodują „,nowe współzależności i nowe różnorodności”, z którymi zarówno przedsiębiorstwo, jak i kadra kierownicza spotykać się będzie na rynkach zagranicznych. Nowe współzależności dotyczą głównie ważności procesów internacjonalizacji, a nowe różnorodności dotyczą funkcjonowania przedsiębiorstwa w złożonym otoczeniu międzynarodowym.

Internacjonalizacja zatem to $\mathrm{z}$ jednej strony nowe szanse, nowe możliwości działania, nowe perspektywy rozwoju i funkcjonowania, ale jednocześnie trudności, bariery w prowadzeniu działalności gospodarczej na zagranicznych rynkach, połączone ze złożonością procesu zarządzania w trudnym, słabo znanym otoczeniu rynkowym i kulturowym przedsiębiorstwa.

\section{Bibliografia}

Adamus-Matuszyńska, A. (2016). Społeczna odpowiedzialność firm w dobie globalizacji. Pobrane z: http://www.ue.katowice.pl/fileadmin/-user_upload/wydawnictwo/SE_Archiwalne/SE_35/05.pdf.

Bloom, H., Calori, R., Woot, Ph.De. (1995). Zarzadzanie europejskie. Warszawa: Poltex.

Kołodko, G.W. (2013). Dokąd zmierza świat. Ekonomia polityczna przyszłości. Warszawa: Prószyński i s-ka.

Kreitner, R., Kinicki, A. (2011). Organisational Behaviour. Irwon: MsGraf-Hill.

Rozkwitalska, M. (2007). Zarządzanie międzynarodowe. Warszawa: Wydawnictwo Difin.

Schoppe, S.G. (2006). Kompendium przedsiębiorstwa (organizacji) w działalności międzynarodowej. Kompendium der internationalen Betriebswirtschaftslehre. Oldenburg: Oldenburg Verlag. 
Vernon, R. (2006). International Investment and International Trade in the Product Cycle. The Quartetly Journal of Economics, 2 (80).

Zbiegień-Maciąg, L. (2006). Etyka w zarządzaniu. Warszawa: CJM.

\section{NOTES ON THE MODERN MANAGEMENT BACKGROUND OF INTERNATIONALIZATION PROCESSES OF ENTERPRISES}

Keywords: management, globalization, internationalization, company

Summary. The study accented is that internationalization generates a completely new system of determinants of work, business enterprises and their managers in the international markets. In the text there are analyzed - according to the author - the most important determinants (problems) that arise when a company internationalizes its activities.

Translated by Bogustaw Kaczmarek

\section{Cytowanie}

Kaczmarek, B. (2017). Uwagi o współczesnym zarządzaniu na tle procesów internacjonalizacji przedsiębiorstw. Ekonomiczne Problemy Ustug, 1 (126/1), 141-148. DOI: 10.18276/epu.2017.126/1-15. 